\title{
Fetal Heart Finding
}

National Cancer Institute

\section{Source}

National Cancer Institute. Fetal Heart Finding. NCI Thesaurus. Code C92715.

An observation of the fetal heart that may or may not be abnormal. 